\title{
Diagnosis of limb-girdle muscular dystrophies in the molecular biology era: do clinical findings still matter?
}

\author{
Diagnóstico das distrofias musculares de cinturas na era da biologia molecular: os dados \\ clínicos ainda tem importância?
}

Lineu Cesar Werneck

\footnotetext{
Universidade Federal do Paraná, Departamento de Clínica Médica/Neurologia, Curitiba PR, Brazil.

Correspondence:

Lineu Cesar Werneck; Serviço de Doencas Neuromusculares, Hospital de Clínicas da Universidade Federal do Paraná; Rua Gal. Carneiro, $181 / 3^{\circ}$ andar sala 310; 80060-900 Curitiba PR Brasil; E-mail: lineu.werneck@ hc.ufpr.br

Conflict of interest:

There is no conflict of interest to declare.

Received 13 October 2015 Accepted 20 October 2015
}

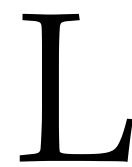

imb-girdle muscular dystrophies have always been a challenge to diagnose because of the similarity of their clinical presentations. Until 1981, differentiation between these dystrophies was relatively simple and was based on age of onset, gender and inheritance pattern. Limb-girdle dystrophies comprised four diseases: (i) autosomal recessive or sporadic limb-girdle muscular dystrophy (Erb, Leyden and Möbius), (ii) myopathy limited to quadriceps, (iii) childhood autosomal recessive muscular dystrophy and (iv) late-onset autosomal dominant muscular dystrophy ${ }^{1}$.

In the following decades, with the diffusion of muscle histochemistry and immunohistochemistry and the identification of genetic defects by molecular biology, the number of classifications of muscular dystrophies increased exponentially. By January 2015, limb-girdle muscular dystrophies comprised eight autosomal dominant forms (LGMD1) and twenty-three autosomal recessive forms (LGMD2) ${ }^{2}$.

The American Academy of Neurology guidelines advocate the use of clinical findings and inheritance pattern to diagnose limb-girdle muscular dystrophies. If the dystrophy has an autosomal recessive inheritance pattern and the patient presents with scapular winging, has normal cardiorespiratory function, does not have calf hypertrophy and is of British, Southern European, Eastern European or Brazilian descent, genetic testing for a calpain-3 (LGMD2A) mutation is recommended as the first diagnostic step ${ }^{3}$.

Mutations of the CAPN3 gene and its allelic variants cause calpain-3 deficiency. Disease onset occurs between the ages of 2 and 45 years and is typically at the age of 14 years. LGMD2A has a variable course depending on the type and combination of genetic alterations and is considered the most common form of muscular dystrophy in Brazil ${ }^{4}$.

If genetic tests are inconclusive, a muscle biopsy with histochemistry, immunohistochemistry and Western-blot can be performed ${ }^{5}$. Next-generation genetic testing is currently available in only a few centers and is still in the validation phase ${ }^{6}$.

This edition of Arquivos de Neuropsiquiatria includes a paper by Albuquerque et al. reporting six cases of LGMD2A in children7. One of the children had calf hypertrophy, but in view of the mutation found in the patient and her sister, this sign can be considered a clinical variant. Although only six children were studied, the authors describe all the available investigative methods, showing the importance of clinical data and correlating these with the findings of investigative methods, such as muscle biopsy and molecular biology.

While molecular biology techniques are becoming increasingly common and replacing other methods, clinical information, such as detailed manual muscle examination or magnetic resonance or ultrasound of the affected limb muscles, is still required ${ }^{8}$. Each type of dystrophy affects a specific muscle group, and the type of genetic testing requested depends on the muscle group affected. Knowledge of the affected muscles also helps to choose the muscle to be biopsied when molecular biology tests are inconclusive ${ }^{9}$.

However, genetic testing and muscle biopsies are still very expensive and not widely available in Brazil or other countries. Furthermore, they are subject to restrictions by government agencies and health insurance companies ${ }^{10}$. Most patients are therefore sent to specialized public hospitals or university centers for investigation.

Despite the many advances in diagnostic techniques made to date, physicians still need the same basic clinical information as in the past to minimize costs and ensure a rational approach to diagnosis. 
1. Walton J, Disorders of voluntary muscle. Edinburgh: Churchill Livingstone; 1981.

2. Kaplan J-C, Hamroun D. The 2015 version of the gene table of monogenic neuromuscular disorders (nuclear genome). Neurom Disord. 2014;24(12):1123-53. doi:10.1016/j.nmd.2014.11.001

3. Narayanaswami P, Weiss M, Selcen D, David W, Raynor E, Carter G et al. Evidence-based guideline summary: diagnostic and treatment of limb-girdle and distal dystrophies: report of the guideline development subcommittee of the American Academy of Neurology and the practice issues review panel of the American Association of Neuromuscular \& Electrodiagnostic Medicine. Neurology. 2014;83(16):1453-63. doi:10.1212/WNL.0000000000000892

4. Paula F, Vainzof M, Passos-Bueno MR, Pavanello RCM, Marioli SR, Anderson LVB et al. Clinical variability in calpainopathy: what makes the difference? Europ J Hum Genet. 2002;10(12):825-32.

5. Comerlato EA, Scola RH, Werneck LC. Limb-girdle muscular dystrophy: an immunohistochemical diagnostic approach. Arq Neuropsiquiatr. 2005;63(2):235-45. doi:10.1590/S0004-282X2005000200009
6. Seong MW, Cho A, Park HW. Clinical applications of next-generation sequencing-based gene panel in patients with muscular dystrophy: Korean experience. Clin Genet. 2015. doi:10.1111/cge.12621

7. Albuquerque MAV, Abath Neto O, Silva, FMA, Zanoteli E, Reed UC. Limb-girdle muscular dystrophy type 2A in Brazilian children. Arq Neuropsiquitr. 2015;73(12):993-7. doi:10.1590/0004-282X20150168

8. Narayanaswami P, Weiss M, Selcen D et al. Evidence-based guideline summary: diagnosis and treatment of limb-girdle and distal dystrophies. Neurology. 2014;83(16):1453-63. doi:10.1212/WNL.0000000000000892

9. Cotta A, Carvalho E, Cunha-Júnior AL, Paim JF, Navarro MM, Valicek $J$ et al. Common recessive limb girdle muscular dystrophies differential diagnosis: why and how? Arq Neuropsiquiatr. 2014;72(9):721-34. doi:10.1590/0004-282X20140110

10. Govindarajan R, Shepard KM, Jones LKJr. Diagnosis and treatment of limb-girdle and distal dystrophies: payment policy perspectives. Neurol Clin Pract. 2015;5(5):454-69. doi:10.1212/CPJ.0000000000000188 